\title{
Acceleration, social time, and consumer culture: notes on (im)possibilities in the field of human experiences
}

\author{
CARLos Victor leal Aderaldo ${ }^{12}$ \\ CASSIO AdRIANO BRAZ de AQUINO ${ }^{2}$ \\ MARIA de FÁtima VIEIRA SEVERIANO ${ }^{2}$ \\ ${ }^{1}$ UNIVERSIDADE DE FORTALEZA (UNIFOR), FORTALEZA - CE, BRAZIL \\ 2 Universidade Federal do Ceará (UFC) / Programa de Pós-Graduação em Psicologia, Fortaleza - CE, Brazil
}

\begin{abstract}
This theoretical article aims to analyze the relationship between time and consumer culture in modernity, and its repercussion in human experiences, starting from a critical perspective of the administration. Authors in the areas of sociology, psychology, philosophy, and administration were used, considering the complexity and multiplicity of the knowledge around the subject. The discussion on consumption was grounded on the work by authors such as Horkheimer, Rosa, Bauman, and Baudrillard. As for social time, the theoretical framework counted on works by Sue, Pronovost, and Durkheim. Finally, the studies by Larossa, Maia, and Perls subsidized the discussion on experience. The article is based on radical humanism (BURREL and MORGAN, 1979), which is situated on the epistemic axis of the Critical Matrix (PAULA, 2016) and considered relevant in the field of administration sciences, given its opposition to most of the specific literature, since they consider functionalist models to study consumption. The study shows that the acceleration of modernity, mainly due to technological intensification, increases the demand for unbridled consumption that materializes through the consumption of products, services, and relationships between individuals. The sense of time shortage coupled with the demand for consumption drives individuals away from experiences, resulting in constant dissatisfaction with the way modernity operates, requiring criticality in the way knowledge is produced in management.
\end{abstract}

Keywords: Consumer culture. Social time. Experience.

\section{Aceleração, tempo social e cultura do consumo: notas sobre as (im)possibilidades no campo das experiências humanas}

\section{Resumo}

Esse artigo teórico tem como objetivo analisar as relações de tempo e da cultura de consumo na modernidade e sua repercussão nas experiências humanas, pela perspectiva crítica da administração. Para isso, foram usados autores da sociologia, psicologia, filosofia e administração, tendo em vista a complexidade e multiplicidade de saberes para abordar os temas. Para tratar consumo, autores como Horkheimer, Rosa, Bauman e Baudrillard foram citados; para tempo social, Sue, Pronovost, Durkheim; para experiência, Larossa, Maia, Perls. Esse trabalho tem como base o humanismo radical (BURREL e MORGAN, 1979) que está situado no eixo epistêmico da Matriz Crítica (PAULA, 2016) e se configura como relevante no campo das ciências administrativas, tendo em vista a contraposição que ele faz a maioria das produções na área, pois elas consideram modelos funcionalistas para estudar o consumo. Com base na abordagem dada nesse artigo, foi percebido que o modo acelerado da modernidade, elencado principalmente pela intensificação tecnológica, amplia a demanda de consumo desenfreado que se materializa pelo consumo de produtos, de serviços e de relações entre indivíduos. A sensação de escassez de tempo, juntamente com a demanda por consumir, afasta os indivíduos das experiências, resultando em constante insatisfação com o modo como a existência é operada na modernidade, exigindo criticidade no modo como o conhecimento é produzido na administração.

Palavras-chave: Cultura do consumo. Tempo social. Experiência.

Aceleración, tiempo social y cultura del consumo: notas sobre las (im)posibilidades en el campo de las experiencias humanas

\begin{abstract}
Resumen
Este artículo teórico tiene como objetivo analizar las relaciones de tiempo y de la cultura del consumo en la modernidad y su repercusión en las experiencias humanas, desde la perspectiva crítica de la administración. Para ello se utilizaron autores de sociología, psicología, filosofía y administración, teniendo en vista la complejidad y multiplicidad de saberes para abordar los temas. Para tratar el consumo, se citaron autores como Horkheimer, Rosa, Bauman y Baudrillard; para el tiempo social, Sue, Pronovost y Durkheim; y para la experiencia, Larossa, Maia y Perls. Este trabajo tiene como base el humanismo radical (BURREL y MORGAN, 1979) que está situado en el eje epistémico de la matriz crítica (PAULA, 2016) y se configura como relevante en el campo de las ciencias administrativas, teniendo en cuenta la contraposición que él hace en la mayoría de las producciones del área, pues estas consideran modelos funcionalistas para estudiar el consumo. A partir del enfoque dado en ese artículo se observó que el modo acelerado de la modernidad, que se centra principalmente en la intensificación tecnológica, amplía la demanda de consumo desenfrenado que se materializa a través del consumo de productos, servicios y relaciones entre individuos. La sensación de escasez de tiempo junto con la demanda de consumir aleja a los individuos de las experiencias, lo que resulta en constante insatisfacción con el modo como la existencia opera en la modernidad, exigiendo criticidad en el modo como el conocimiento se produce en la administración.
\end{abstract}

Palabras clave: Cultura del consumo. Tiempo social. Experiencia. 


\section{INTRODUCTION}

Rapid and significant transformations can be seen in modern society. The way in which time is conceived of, the human relations involved in consumption and the reflection of these aspects in the formation of subjectivities can be observed in various western cultures (BAUMAN, 2003; BAUDRILLARD, 2005; LIPOVETSKY, 2007). These cultures highlight work in relation to other spheres of social organization. It is not by accident - and this has not happened suddenly - that work has become the regulatory institution of other social time, dominating the way in which they are conceived of within human relations (SUE, 1995). And it was important that profound technological transformations, including the instrumentalization and quantification of time and the promise of satisfying needs through consumption, operated so that this occurred.

The centrality of work for social organization is not only the time dedicated to it, but what it represents during the time that is not devoted to work. Leisure and free time have been merchandized and made into fetishes in a consumption logic that captures individual desires and converts them into merchandise (SEVERIANO and ESTRAMIANA, 2012). Individuals treat themselves as objects of other peoples' consumption when they make posts of love, friendship and pleasure on social networks seeking intersubjective recognition.

The patterns of consumption oriented by modernity subject individuals to being always up to date with the latest technology, to never stop working, and making themselves endlessly flexible to meet daily demands. Time is crammed with various simultaneous activities and the feeling of "a lack of time" has become common. Time is monetarized, compressed and manipulated, because it is marked by urgency, leading to complex and diffuse organizations of temporality (PADILHA and JORGE, 2015). Life rhythms are accelerated by technological and social acceleration, which have a great impact on the production of subjectivity (ROSA, 2003).

Hyper-consumption and hedonism cultures are integrated within the social context, and this leads individuals to focus exclusively on the satisfaction of their most immediate pleasures, and ensures that a sense of collectiveness and being part of society become fragile feelings (VALADARES, VILAS BOAS, REZENDE et al., 2016). The hedonistic immediatist discourse interjected between individuals does not allow postponement; it is in today that we guarantee the idea of the future, in a manner that is progressive and decontextualized in terms of the past. The misalignment between what is projected socially and human experiences is filled with promises of what will come, and equally by consumption, and subjectivities are fragilely constituted as mere collages of the need for social recognition. Instead of this, it is necessary to discuss what can be rethought in this discourse that promotes endless decontextualized consumption and the denaturalization of these positivist and functionalist biases.

In this sense, Padilha and Jorge (2015) emphasize the contributions and critical perspectives of administration, such as the critical theory of organizations, Critical Management Studies and Critical Organizational Studies, which break with the functional model guided by management discourses of efficiency and effective organizations. This rupture is important to the extent that administration need to consider a macro-social context, macro-economics, and macro-politics, instead of focusing soling on strategies to obtain the greatest profitability and competitiveness (PADILHA and JORGE, 2015).

In the area of marketing, Scussel (2017) stresses that most production emphasizes the adoption of strategies to increase consumption, but it is necessary to have an epistemological posture distinct from the understanding of complex social phenomena, requiring dialogue with other fundamentals and sociological methodologies. The author also points out the importance of considering processes of subjectivation in their totality in place of the attention given to objective reason, seeking to advance administrative studies.

It is important to state that studies can be theoretical or practical. Maranhão and Vilela (2017), as well as Adorno (2009) in his work Negative dialectic, emphasize the importance of practical field studies, even though the majority of administration studies are based on critical theory. In this manner, the negative dialectic in administration does not occur with the polarities of the primacy of the real (field) or the primacy of the ideal (theory). It is in the interrelationship between these two perspectives that there is the possibility of the comprehension of social phenomena, considering the historicity of the discourses and the contradictions which emerge from the versions of the reality that they fixate on as real (MARANHÃO and VILELA, 2017).

That being so, this work is based on radical humanism (BURREL and MORGAN, 1979) situated on the epistemological axis of the Critical Matrix (PAULA, 2016), given that the categories addressed in this article - consumer culture, social time and experience 
- have received various contributions from the critical theory developed during the $20^{\text {th }}$ century and the Frankfurt School. In administration, other studies relate critical theory to the broadening of studies in this area, such as the contributions of Debord and the analysis of the spectacle society (GORIBA, LIMA and CARRIERI, 2015), hedonist culture, the hyper-consumption society (VALADARES, VILAS BOAS, REZENDE et al., 2016), and the emptying of the meaning of work through worker managerialist practices (ROHM and LOPES, 2015), among others.

Given this, the objective of this article is to analyze the relationships between time and modern consumer culture, and their repercussions on human experiences, making this the basis for a critical perspective of administration. Due to their complex nature, they contribute to a multi-disciplinary approach referencing authors in sociology, psychology, philosophy and administration. Initially we will analyze social time to explain its relationship in the formation of subjectivities. Next, the fundamentals of acceleration and the consumer society will be presented based on critical theory studies, because these references are considered relevant to the understanding and denaturalization of the discourses of modernity. Finally, we will reflect on experience and how it is affected by subjectivity, highlighting the need to rethink the ways in which studies of consumption are conducted within the field of applied social sciences.

\section{Social Time}

Time is a research object that interests various areas of knowledge such as Physics, Sociology, Psychology, Philosophy and Religion. This multiplicity of approaches is justified by the complexity of this category: if, on one hand, it can be thought of in terms of aspects related to its nature, space and instruments of objective measures delineated by man, on the other, it can also be seen through the social and psychological aspects that constitute it (AQUINO, 2003).

In fact, time is a complex category which gives meaning to natural and social events (ELIAS, 1997). The succession of natural events is based on time - the time of day, night, seasons, and it also possesses a social character, because lives are organized around time, following the time of planting, harvesting, rain and drought. In addition, instruments for the measure and categorization of time have been created by each society, giving meaning and organizing the rhythms of life. The creation of calendars and the meaning attributed to systematized events dealing with time can be observed in the most widely varied civilizations (ELIAS, 1997).

Calendars give meaning to a civilization's traditions and customs, organizing them and constitute meanings shared by them. In this way, lives and subjectivities form a network of symbiotic interaction. Time and its demarcations and measurements organize the history of humanity, because they relate to the habits, styles and modes of social groups (SEVERIANO and ESTRAMIANA, 2012).

This can be seen in various civilizations in antiquity, such as the Mayans, whose conception of time was ordered, fixed, logical and circular. Social organization was based on cycles of specific duration, retaking the initial step of creation after periods counted by time.

With Christianity, the notion of time was reformulated in a linear model; the beginning occurred after divine creation and will end after the final judgement day (AQUINO, 2003). The notion of linearity corroborates historical models of the understanding of time and human events, because events are categorized based on a succession of moments which are summed for the understanding of societies.

Modern conceptions of time have evolved its objective and subjective nature. In terms of objectivity, it can be understood through its own character and independently as a succession of natural events. Subjectively it can be understood by stories which are described by social events, which organize it and create it, keeping in mind the development of mankind and societies. Durkheim (1985) states that time is a collective social construct of individuals who share common meanings for social organization. With Durkheim, the nature of social time gains importance as an object of study of the social sciences. To the author, each moment is marked by a social time which determines various customs and values in civilizations.

Unlike Durkheim, Sue (1995) adopts the understanding of various social times, rather than just one. The dominant social time organizes other diverse activities and times, keeping in view the influence of this on other social times. According to the author, social time possesses three characteristics: 
a) it is cyclical, regular and reversible. It precedes the constitution of societies and is part of this history, demarcating the founder myth at regular intervals;

b) while representing mythical history, it is the organizer of duration (calendars, for example);

c) social time is the place of a society's symbolic production.

All that is related to the dominant social time is valued to the detriment of other activities related to other social times. The transformation of temporalities may be observed relative to free time, which has also come to be dedicated to consumption and production (SEVERIANO and ESTRAMIANA, 2012), or in other words, free time has been subjugated to culture and consumption, expanding the possibilities of merchandizing lives and subjectivities.

In modern times, work time has become the most important social time, subjugating other temporalities. The creation of a work day during the industrial revolution organized society's time according to productive time, chronologically regulated by large industries. The use of watches in industries was later adopted by workers, who transformed their time in virtue of work and came to self-regulate themselves by using watches (CHANLAT, 1996). Pronovost (1996) points out that these transformations of temporality produced changes in the world of labor as well as the organization of society.

In this sense, the discourse of productivity and work soon are present and central to subjectivity and the constitution of human identity, with the rest being considered "a waste of time" and therefore deserving of condemnation. Corroborating this idea, Munné (1980) emphasizes that social time related to work (socioeconomic time) superimposes itself in relation to other social times. To the author, social time can be extended to form four perspectives: psychobiological time; socioeconomic time; sociocultural time; and free time.

Psychobiological time is understood to be the physiological needs based on sleep, nutrition and reproduction. It's an individual and self-conditioned time.

Socioeconomic time is that which has been historically valued by working society. It refers to the time needed to fulfill fundamental economic needs, such as work, study, and other demands which have been conditioned, for the most part, by society.

Sociocultural time refers to the demands of sociability that result from compromises with the value and cultural systems of a given population. It is a dimension of temporality that can be conditioned externally and internally by the individual.

The fourth dimension is free time, and this category should be related to the needs of the individual, offering freedom and creativity.

As stated above, various social times have been transformed by work time, or in other words, by socioeconomic time. Excessive valuing of work time appears in modernity as western societies articulate themselves in terms of it, reducing or transforming other social times. In organizations this materializes in management models that seek the maximization of processes of organizational efficiency, reducing idle time, and minimizing the importance of subjective aspects related to work (GAULEJAC, 2007; PADILHA and JORGE, 2015). Time unassociated with production loses its relevance from the point of view of the management discourse and the optimization of profits, imposing on workers a temporal logic that is disconnected from their physical, psychological and social needs.

In Brazil, this can be seen in the worker reforms approved by Decree-law 5,452 (BRASIL, 2017) of July 14, 2017 when the time allotted for lunch was made flexible, leading individuals to change their psychobiological rhythms to meet the demands of capital. Many workers had their quantity of sleep reduced in complying with their work load, leaving other aspects of their social sphere aside.

Even though the presence of the individual is demanded at work, the pressure exercised by productivity and the suppression of other temporalities by the organization result in a disconnect between the worker and the activities that the worker realizes, whether this is due to fatigue, or a loss of meaning or health, among other motives. Camargo (2017) terms this phenomenon presentism, in which the worker is physically present at work, but the worker's mind is thinking of other issues, making this presence partial and dividing the worker's attention with other objective and/or subjective needs.

The fragmentation and partial nature of individuals in their activities establishes a relational nexus with work conditions and environmental and organizational dimensions, with the presentism being the motor of psychosocial risks at work (CAMARGO, 2017). The intensity and the time of work are one of these risks which are translated with a temporality designated by the 
organization for each workday activity. The design of tasks occurs in a fashion that is removed from the worker, and the incidence of the cult of productivity ignores time that is necessary for health, one's presence and the experience of individuals. Many of them seek in other temporalities the experience which has been taken from them at work.

Sociocultural time has been transformed into merchandise and consumption. In parallel, free time has been transformed into consumption by the cultural industry, which has merchandized leisure and converted into an object of adoration (PINHEIRO, RHODEN and MARTINS, 2010; SEVERIANO, 2017). The right to leisure has transformed itself, supposedly in merit for work, and it also has to be profitable to society, which retro-feeds its merchandization.

The centrality of work in modern times can be seen not only during work time, but also in terms of non-work being linked to activities that need to be consumed as a result of labor. Subjectivities are circumscribed in rapid contexts characterized by perennial transformation (BAUMAN, 2003), in which individuals seek experiences through consumption, whether this is through objects announced through media, or even the consumption of human relationships themselves (SEVERIANO, 2013).

Sue (1995) highlights some characteristics of modern western societies that have been imported for the naturalization of transformations of social times:

a) the legitimation of the value of time: time gains economic value and is conducted by a logic tied to work and the value of production;

b) measurements of time: time is regulated and timed in its quantitative value. These measurements such as days, hours and minutes are superimposed on subjective experience or the qualitative understanding of time;

c) temporal strategies: in the organization of modern societies, the understanding of time is directed towards the future. Development ideas are activated by the discourse of what is to come, and that one needs to do something today to guarantee the future;

d) temporal horizon: individual and collective activities are organized around the dominant social time; in this case, work. Life projects and the representation of the future are related to this activity.

These characteristics, allied to the process of technological advances, dictate lives which are articulated by acceleration processes, and are devoted to satisfying needs that before didn't even exist (SEVERIANO, 2013). The monetarization of time, which turns time into money, directs an entire society to the satisfying of created needs and desires, mobilizing individuals for a more intense process of distancing from their experiences.

\section{Critical Theory, Acceleration and the Consumer Culture}

The studies and the contributions of the Frankfurt School's critical theory emerge in a between the wars context and seek, among other things, to question the mode of ordered, natural, determined and positivist scientific production that was dominant at the time. Horkheimer (1983) points out that traditional theories, which in trying to establish causal relationships based on deductive processes, are not sufficient to understand social phenomena. The positivist nature of science is incapable of understanding these phenomena in their complexity, with it being necessary to have a critical bias, which denotes, equally, the influence of the researcher on the construction of the study.

Critical theory made viable the deconstruction of the positivist and cartesian process of the formation of knowledge in the social sciences, making it possible to reflect based on a negative, dialectic and emancipatory philosophy (GOBIRA, LIMA e CARRIERI, 2015; PAULA, 2016). It also contributes to administration studies that seek to avoid dichotomizing social reality, and the discursive construction of these realities, because one cannot understand the object of study isolated from its context (MARANHÃO and VILELA, 2017).

However, articles which have the critical perspective as a theoretical reference and a negative philosophy have not been sufficiently explored within the field of administration which demands a theoretical development that sustains a practice based on an ethical-political posture by area researchers. Support from the Social Sciences, Anthropology, Philosophy and Psychology are necessary to broaden the discussions that historically have been directed towards functionalist models of the production of knowledge. This being so, we have sought, based on Critical Matrix studies (PAULA, 2016), the: 
[...] amplification of a debate to instigate discussions which are sometimes uncomfortable and challenging to the dominant logic, bringing themes which are fundamental to a more human and egalitarian society, within which business activity is capable of reflecting the real interests of this society (SCUSSEL, 2017, p. 543).

In the field of applied social sciences, Padilha and Jorge (2015) point out that the critical theory in organizations breaks with the positivism of traditional theories, because it considers as central aspects: the contradictions, dominant ideology, the dominant rationales, the socio-historical context, the emancipation processes, and individual and collective consciousness. Even though it is not possible to attain the absolute freedom of the individual, given discursive practices, and the social, economic and political context, critical theory proposes a reflective practice which breaks the established paradigms. Thus, the unidimensional and alienated perspective has been substituted by reflections which promote emancipation and the reconfiguration of naturalized discourses by the reigning system (PADILHA and JORGE, 2015).

It is necessary, therefore, to utilize multiple methods to understand social phenomena (SCUSSEL, 2017), opting for a debate between human sciences and applied social sciences. Serva (2017), in conducting a panoramic look at administration studies in Brazil, highlights eight explored dimensions. Among these dimensions she mentions the "debate about epistemological and philosophical options", which characterizes the productions that seek to dialogue with critical perspectives to broaden organizational studies, such as methodologies of historical research, which use the systematization, collection and evaluation of the data, emphasizing historical-social contextualization in the production of area knowledge (COSTA and SILVA, 2019). Based on the critical perspectives cited, one can understand how the naturalization of the acceleration process experienced in modernity came about, which is central to understanding the organization of subjectivities inherent in the consumer culture (ROSA, 2003; MAIA, 2017). Temporality is a characteristic that gives meaning to social order and history, and as a consequence it influences the formation of subjectivity. The acceleration of the social context transforms values and behaviors, as do relationships between individuals, as life rhythms are reconfigured to meet socially created patterns.

Hartmud Rosa (2003) discourses about three distinct forms of acceleration: technology, social change, and life rhythms. These forms are interrelated and promote a retro-alignment of acceleration processes:

Figure 1

Forms of Acceleration

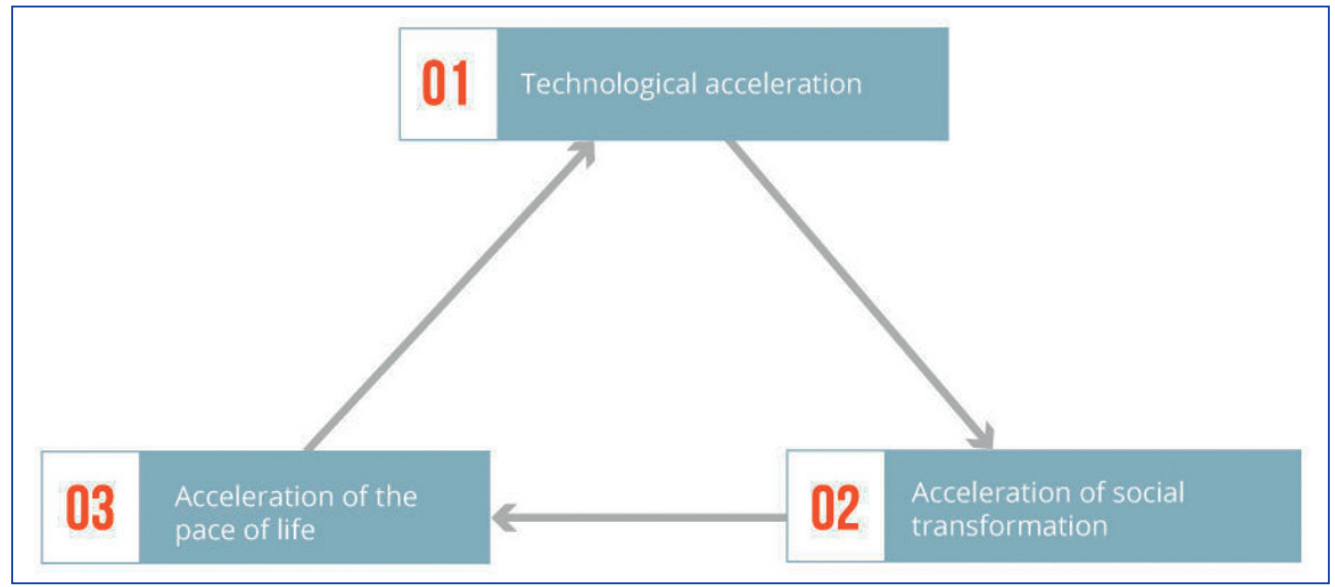

Source: Rosa (2003, our translation).

The process begins with technological acceleration derived from advances in information technology, robotics, communications and smarthphones, among other things. Computers and other technologies which are more advanced, intensify the number of activities that can be realized at the same time. The immediate social objective is to economize time, which leads to changes in social structures to be integrated in multitask based organizational models (ROSA, 2003), which can be perceived 
in various contexts within society. Productive models eliminate idle time and intensify work time for individuals (DAL ROSSO, 2017); in terms of communications, information is presented in a rapid, simultaneous fashion, without there being time for the assimilation of presented content, among other things.

In addition, social changes, referring to rapid transformations in values and customs are also influenced by technology. Cultural aspects which were valid for many years, now are valid for shorter periods, so that procedural changes in different generations are substituted rapidly within the same generation. What is valid and acceptable today ceases to be valued in the near future, which demands that people within this context must remain up to date with greater frequency (ROSA, 2003; MAIA, 2017).

Social acceleration promotes the separation of experience in relation to the expectations of subjects, diminishing the stability of time due to the compression of the present. If the individual is encouraged to perform various activities simultaneously with the preoccupation of "not falling behind", the result of this is a emptying of the experience, because the circumstances of the action and lifestyles lose meaning in time spans that are shorter and shorter, which gives the impression of a lack of time (ROSA, 2003). Derived from this context, there is an acceleration in the rhythms of life, because in the attempt to handle the social changes produced by the acceleration of technology, individuals accelerate their lives through the consumption of technologies that seek to inhibit the sensation of emptiness. Thus, the need appears to have various experiences in a shorter period of time, which distances the subjects from their own experience and the formation of meaning (LAROSSA, 2002; MAIA, 2017).

Technological acceleration plays an important role in the change of the space-time relationship prioritizing the latter, keeping in mind greater free time for the realization of other activities. Paradoxically what is observed is the sensation of a lack of time because of the accelerated life rhythms (MAIA, 2017), because the quantity of tasks that need to be accomplished grows exponentially with technological acceleration. If before it took a morning to write three or four letters, today one has to read and respond to forty emails during the same amount of time (ROSA, 2003).

Acceleration is the fundamental characteristic of modernity. The idea that technological advances can resolve a series of problems and delays suffuses social discourses and they are made natural by accelerated life rhythms (SEVERIANO, 2013; MAIA, 2017). Fast food, the internet, robotics, cell phones and hyper-connectedness offer the sensation of facility and quickness of connection, with the immediate satisfying of any need. If before there was a delay in the delivery of mail, currently e-mails, messages and images are sent and received instantaneously, which leads the individual to always have the supposed opportunity of knowing what is happening everywhere at all times.

Social relations and customs are transformed to the extent that technology substitutes in-person meetings with long-distance conferences, in which in-person affection is exchanged for likes and comments on social networks, and people substitute the relating of their own experiences for stories of success or happiness constructed on social networks to be consumed by others. Conditions are created in which we lose the capacity to look at the other beyond the merchandise that this person has become. In parallel, individuals lose the capacity to see themselves in this process, because these practices are gradually absorbed by the subject, establishing conditions which ruin the capacity to interpret and reflect on reality (VALADARES, VILAS BOAS, REZENDE et al., 2016).

Bauman (2001) emphasizes that consumption, whose purpose before was to satisfy the needs of individuals' biological and social survival, ceases to be relevant when these needs are satisfied. To the author, consumption becomes the purpose of social organization in modernity, and the consumer society becomes self-propelling, which proclaims the impossibility of satisfying needs and the continuity of the state of tension in seeking to satisfy them.

Individuals come, therefore, to consume pre-formatted lifestyles, transforming themselves into, and considering others as, merchandise. Consumer relationships establish themselves as the predominant social order, and the sensation of emptiness as well as the desire to fill it becomes common in a society saturated with subjectivities sustained by empty images.

Severiano (2017) points out that the consumer society and culture go beyond the products and services produced by capitalism. In fact, consumption extends to the production of markers of subjectivity, which prescribe how to be, think and feel. Within this, there are mechanisms of socialization, of exclusion and social inclusion, keeping in mind the place of intersubjective recognition that it promotes. 
The author defines consumer culture:

[...] as that in which consumption establishes itself as a source of identity reference and is the preponderant factor in the production of subjectivities and social recognition; when people consume images, places, people, lifestyles, it in turn signifies and prescribes given ideas, ways of being, loving and feeling (SEVERIANO, 2017, p. 85).

Rosa $(2003,2017)$ also notes that we are conducted to consume even more and we become merchandise through the lifestyles that we create. There is the search to surpass what was consumed the previous year, and this coercion affects the self-understanding of the individual ethos, giving the individual a sense of incompleteness and a desire for a type of growth, to distance oneself from one's previous incarnation.

The process operated by neoliberalism appears in various forms of capitalism that are absorbed by subjectivities, in which people change lifestyles to be a part of it, and replicate mechanisms that transform themselves and others into objects of consumption (BAUMAN, 2001; BAUDRILLARD, 2005; ROSA, 2017).

How has this become possible in modernity?

Rosa (2017) alerts that the pathologies of capitalism, which modify lifestyles, generate irrationality, detemporalization, and alienation. To the author, irrationality appears as an imperative of progress and growth. Even if many resources have been used up or much has been done, the idea that guides these subjectivities is that there has to be constant growth and progress at all cost, ignoring the progress already achieved. History, the past and traditions constructed over years are no longer considered, because they are perceived as obsolete, antiquated or in disuse, and this moves society in the direction of progress and growth which are rapidly viewed as the past.

Detemporalization, meanwhile, refers to acceleration phenomena in which everything needs to be planned today to achieve happiness or a desired lifestyle in the future, even though tomorrow can completely change what has been imagined for this future, or in other words, an acceleration of social changes (ROSA, 2003, 2017).

Alienation is treated as an intensification not only of the alienation of the means of production but also alienation itself. Individual desires are destructured in collectively affirmed duties: the individual cannot exist without a cell phone of the latest generation, without social networks, and without using the latest technologies to "gain time", and cannot refuse to be flexible in handling the demands of work. In terms of this last aspect, Sennett (1999) emphasizes the transformation of lives due to the demands of the work world, which also change how individuals relate to each other and constitute their subjectivities. To the author, short term relationships and intermediary technologies weaken social ties which are developed at work, transforming individuals into gears or particles of a process which ends when the project or activity is no longer necessary. Workers and life stories become obsolete in societies that accelerate in the short term.

Talking further about the pathologies of capitalism, Rosa (2017) reiterates that the way the system works distances us from ourselves, from our experiences that give us meaning. The debate about these pathologies arises as a possibility for retrieving individual experiences, in place of rapid and fluid access to human existence.

\section{Notes about Experience}

Modern society imposes accelerated lifestyles oriented towards performance and an ideal of happiness announced in the form of consumption. Having "no time to lose" dissimulates the laying of blame to the individual for the failures of a symptomatic society. Kehl (2009) presents narratives of freedom, of autonomy, of happiness as counterparts to emotional illnesses which arise in the form of depression today. The growing manifestation of illnesses reveals pathologies which shouldn't be considered in isolation, but should rather be considered social pathologies (KEHL, 2009).

It is precisely when we face a scenario with various forms of information and instructions from society, that we become ill and lose the meaning of existence. Drowning in rationalizations and words, we learn to repeat not just thoughts and phrases, but also meanings. These are formed socially and formatted in everyday life, directing choices which distance us from meanings constructed by the individual. 
"[E]xperience is what happens to us, what touches us" (LARROSA, 2002, p. 21). Many things happen to us, but few touch us. Information cedes space to experiences with meaning, and we name existence in accordance with something that is external to us. Work, school, family, an amorous relationship, friends and leisure, among other things, are valued based on what is expected by the consumer society. What is "expected" by part of the consumer society, is that we repeat cultural values and practices that have little to do with felt experience.

There are various contemporary mechanisms that destroy these experiences. Acceleration itself, the excess of information and cultural dictates distance us from ourselves. Information becomes opinion when our reaction makes subjective what has happened to us, but opinion is not experience, which requires real engagement and the appropriation of the individual of his or her own existence.

Living without existing or having information without experimenting are internalized while life possibilities are immersed in accelerations. Knowledge is laid aside in these repetitions, and "laying aside" one's own experience is affirmed as a condition for survival in the current world.

However, subjective death occurs when there is no questioning about the speed to which all of us are subjected. When contemporary acceleration becomes natural, we may perceive that humans turn into anxious automatons, who don't necessarily suffer deeply, but have little experience with the creative life (PERLS, 1988). It's as if experimenting is left for post-acceleration, but acceleration never ends by itself. The individual needs to ressignify a taste for things and for life.

Larrosa (2002) states that experience requires stopping; stopping to think, to look, to listen. A stop to taste, to feel, to live. Letting oneself, cross, suffuse, extend. This means questioning something which makes sense to the subject. Experience is not made up of information external to the subject, but rather implies transforming what is external to something internal, transforming the external into something of one's own, something singular. In this sense, we reencounter what is thought, felt and lived individually.

To the author, experience is the path of the transformation into who an individual is, not who they say an individual has to be. It's something that requires an opening to affirm what is important to the individual, without this being dictated exclusively by an external scenario. It demands a different posture in the face of existence: a respect for one's individual way of being. This involves avoiding being formatted and placing oneself as the author of one's own existence; being the protagonist and not having a supporting role in one's own life.

Being oneself demands a certain fundamental daring, as well as questioning imposed external truths. Being oneself can be challenging, but at the same time, it is recovering experience with meaning, distancing oneself from the subjective deaths that we are exposed to daily. Life rhythms external to individual meaning, products and services consumed in an active or passive manner by people who haven't had the opportunity to question their own desires, are life conditions that are suffused by a cultural industry that transforms us into products, and thus we consume each other mutually.

In addition to the immediatist perspective, accelerated and fleeting, it becomes urgent to deaccelerate and relearn tastes. Movements which seek slowfood, slowlife and mindfulness, among others, appear as necessary aspects of the reintegration of experiences. Even though we are immersed in a context that generates a sensation of "temporal hunger" in individuals, or in other words, an anxiety to realize various activities at the same time, diminishing the present experience (MAIA, 2017), it becomes imperative that we have the critical ability to reinvent ourselves in this hyper-accelerated society. Recovering experience assumes precisely the recognition of our ancestors and the traditions that form us, as well as the possibility of future projects. The compression of the present in fragmented instants is characteristic of accelerated times. Thus, experience demands a temporal distension, in which past, present and future are recognized. 


\section{FINAL CONSIDERATIONS}

The construction of an ethos centered around singular experiences demands critical reflection about the social context within which we live. The dominant social time in modernity can be understood through the centrality of work, and this occurs in two manners: on one hand, most of the time is dedicated to work, and the other, free time, captured by consumption becomes ruled by the same instrumental and competitive logic as work.

Subjectivities are, therefore, delineated according to the consumption that establishes itself as the founding category of social activities. Not just products are consumed. Individuals themselves are turned into objects, staking their value on recognition in social networks in relation to their lifestyle, which includes likes, selfies, patterns of friendship, happiness and love. It becomes necessary to always be up to date to not lose that which multiple activities offer, even though this imposition of keeping up to date is not contextualized in the processes of society's technological, social change and life rhythm acceleration.

It is in this sense that experiences, that which we conceive in light of the thinking of Larossa, are left to the side, because they demand time, taste and presence. How can one have experiences in a society centered around consumption, the most innovative, the most modern, the simultaneous, the super-connected and the future? Under these conditions, individuality loses itself in a network of relationships doted with collectively shared meanings, but meanings that do not make sense because they do not have the taste of experience which can be felt by an individual.

In the field of applied social sciences, reflection on temporalities, acceleration and the consumer culture is equally necessary for the critical perception of management models which present themselves as innovative. In some moments, these management models act in the replication and in the strengthening of acceleration and consumption processes which alienate and rob individuals of their experiences. Management, efficiency and effectiveness discourses alienate meanings which are fragmented because they are not integrated in an individual's history and values.

To become part of organizations that sustain management practices, workers are encouraged to renounce their own subjectivities, where managerialist models reign that undermine them. This occurs in various forms, such as the supplying of technological resources, the improving of strategies that encourage consumption and the concomitant imposition of times that seek to delineate work with greater productivity, generating a mismatch and a constant sensation of not being able to keep abreast of the activities and novelties of the market. Thus, functionalist and positivist models of administration have been predominant, stimulating studies of strategies and technological advances in favor of productivity to the detriment of worker experiences, leading to presentism and a mismatch of temporalities.

In this sense, what we observe is that critical, dialectic and negative perspectives are still incipient in administration. Historicalsocial, critical and committed contextualization to understand the transformations of society is important to the extent that it indicates the ethical-political commitment of the researchers, who should seek to understand reality in a dialectic form in the place of the cartesian model. And it is this understanding which makes possible the necessary discursive changes which distance individuals from their experiences.

Theoretical and methodological support from other sciences, such as Sociology, Psychology and History can help expand the study of Administration. Dialogue with researchers and studies from other areas tend to develop perspectives that have not been explored by various areas of knowledge, in terms of theoretical as well as practical research.

The authors recognize that many aspects of this study can and should be explored more deeply. In addition to the theoretical categories presented, other studies may be conducted to broaden the notion of acceleration, consumer culture and the experience of given social groups. For example, do these categories relate to youths, which are considered a distinct socioeconomic class? How should we construct these categories for specific groups of workers, such as those who work directly with social communications, social media and even teleworkers? What other theoretical perspectives and methodologies can be adopted to understand the experiences of modernity? How does this process occur with informal workers?

Qualitative, quantitative and mixed studies can be conducted to elucidate all of these aspects. 


\section{REFERENCES}

ADORNO, T. Dialética negativa. Rio de Janeiro: J. Zahar, 2009.

AQUINO, C. B. Tiempo y Trabajo: un análisis de la temporalidad laboral en el sector de ocio - hostelería y turismo - y sus efectos en la composición de los cuadros temporales de los trabajadores. 2003. 459 f. Doctoral Dissertation (Doctor Degree in Social Psychology) Universidad Complutense de Madrid, Espanha, 2003.

BAUDRILLARD, J. A sociedade de consumo. Lisboa: Edições 70, 2005.

BAUMAN, Z. Consuming Life. Journal of Consumer Culture, Oxford, v. 1, n. 1, p. 9-29, 2001.

BAUMAN, Z. Modernidade líquida. Rio de Janeiro: Zahar, 2003.

BRASIL. Decreto-lei n. 5.452 de 14 de julho de 2017. Reforma Trabalhista, Brasília, DF, July 2017.

BURRELL, G.; MORGAN, G. Sociological paradigms and organizational analysis. Elements of the sociology of corporate life. Vermont: Ashgate, 1979.

CAMARGO, M. L. Presenteísmo: denúncia do mal-estar nos contextos organizacionais de trabalho e de riscos à saúde do trabalhador. Revista Laborativa, São Paulo, v. 6, n. 1 (esp.), p. 125-146, 2017.

CHANLAT, J.-F. (Org.). 0 indivíduo nas organizações: dimensões esquecidas. São Paulo: Atlas, 1996.

COSTA, A. S. M.; SILVA, M. A. C. A Pesquisa Histórica em Administração: uma Proposta para Práticas de Pesquisa. Administração: Ensino e Pesquisa, Rio de Janeiro, v. 20, n. 1, p. 90-121, 2019.

DAL ROSSO, S. $\mathbf{O}$ ardil da flexibilidade: os trabalhadores e a teoria do valor. São Paulo: Boitempo, 2017.

DURKHEIM, E. La división del trabajo social. Barcelona: Planeta, 1985.

ELIAS, N. Sobre el tiempo. México: Fondo de Cultura Económica, 1997.

GAULEJAC, V. Gestão como doença social: ideologia, poder gerencialista e fragmentação social. São Paulo: Ideias \& Letras, 2007.

GOBIRA, P.; LIMA, O.; CARRIERI, A. Uma "sociedade do espetáculo" nos/dos estudos organizacionais brasileiros: notas críticas sobre uma leitura incipiente. Cadernos EBAPE.BR, Rio de Janeiro, v. 13, n. 2, p. 257-285, 2015.

HORKHEIMER, M. Teoria tradicional e teoria crítica. In: CIVITA, V. (Ed.). Textos escolhidos: Benjamin, Horkheimer, Adorno, Habermas. São Paulo: Abril Cultural, 1983. p. 117-154. (Os Pensadores).

KEHL. M. R. O tempo e o cão: a atualidade das depressões. São Paulo: Boitempo, 2009.

LAROSSA, J. B. Notas sobre a experiência e o saber da experiência. Revista Brasileira de Educação, Campinas, n. 19, 2002.

LIPOVETSKY, G. A felicidade paradoxal: ensaio sobre a sociedade de hiperconsumo. São Paulo: Companhia das Letras, 2007.

MAIA, A. F. Aceleração: reflexões sobre o tempo na cultura digital. Impulso, Piracicaba, v. 27, n. 69, p. 121-131, 2017.

MARANHÃO, C. S.; VILELA, J. R. de P. X. A imanência entre a teoria crítica e a pesquisa empírica: contribuições para os estudos organizacionais. Organizações \& Sociedade, v. 24, n. 82, p. 476-490, 2017.
MUNNÉ, F. Psicosociología del tiempo libre: un enfoque crítico. México: Trillas, 1980.

PADILHA, V.; JORGE, T. M. A sociologia e o mal-estar na formação de administradores. In: PADILHA, V. (Org.). Antimanual de gestão. São Paulo: Ideias\&Letras, 2015. p. 321-354.

PAULA, A. P. P. Para além dos paradigmas nos Estudos Organizacionais: o Círculo das Matrizes Epistêmicas. Cadernos EBAPE.BR, Rio de Janeiro, v. 14, n. 1, p. 24-46, 2016.

PERLS, F. A abordagem gestáltica e testemunha ocular da terapia. 2. ed. Rio de Janeiro: LTC, 1988.

PINHEIRO, K. F., RHODEN, I.; MARTINS, J. C. O. A experiência do ócio na sociedade hipermoderna. Revista Mal-estar e Subjetividade, Fortaleza, v. 10, n. 4, p. 1131-1146, 2010.

PRONOVOST, G.; Sociologie du temps. Bruxelles: De Boek Université, 1996.

ROHM, R. H. D.; LOPES, N. F. O novo sentido do trabalho para o sujeito pós-moderno: uma abordagem crítica. Cadernos EBAPE.BR, Rio de Janeiro, v. 13, n. 2, p. 332-345, 2015.

ROSA, H. Social Acceleration: Ethical and Political Consequences of a Desynchronized High-Speed Society. Constellations, v. 10, n. 1, p. 3-33, 2003.

ROSA, H. Contra a invisibilização de um "poder fatídico": apelo à renovação da crítica do capitalismo. Tradutor: Arthur Bueno. Perspectivas, São Paulo, v. 49, p. 17-36, 2017.

SCUSSEL, F. B. C. Poder, paradigmas e domínio na pesquisa em marketing no Brasil: uma análise da produção nacional da disciplina a partir das matrizes epistêmicas. Administração: ensino e pesquisa, Rio de Janeiro, v. 18, n. 3, p. 518-557, 2017.

SENNETT, R. A Corrosão do caráter: consequências pessoais do trabalho no novo capitalismo. Rio de Janeiro: Record, 1999.

SERVA, M. Epistemologia da administração no Brasil: o estado da arte. Cadernos EBAPE.BR, Rio de Janeiro, v. 15, n. 4, p. 741-750, 2017.

SEVERIANO, M. F. V.; ESTRAMIANA, J. L. A. "Tempo livre" e "tempo do trabalho": a dissolução das fronteiras temporais. Cuadernos de Psicologia, Barcelona, v. 14, p. 67-76, 2012.

SEVERIANO, M. F. V. A juventude em tempos acelerados: reflexões sobre consumo, indústria cultural e tecnologias informacionais. Política \& Trabalho (Online), João Pessoa, v. 1, p. 271-286, 2013.

SEVERIANO, M. F. V. Aceleração Social e Cultura Digital: novas formas de dominação. Revista Comunicações, Piracicaba, v. 24, n. 2, p. 83-101, 2017.

SUE, R. Temps et ordre social. Paris: PUF, 1995.

VALADARES, J. L. et al. O “cidadão hedonista”: diálogos sobre consumo e cidadania na sociedade contemporânea. Cadernos EBAPE.BR, Rio de Janeiro, v. 14, n. 4, p. 966-983, 2016. 
PhD Student in Psychology in the Graduate Program of Psychology of the Federal University of Ceará (UFC); Assistant professor of the University of Fortaleza (Unifor), Fortaleza-CE, Brazil. E-mail: aderaldo@hotmail.com

Cassio Adriano Braz de Aquino

ORCID: https://orcid.org/0000-0001-8651-1634

PhD in Social Psychology from the Complutense University of Madrid (UCM); Adjunct professor of the Federal University of Ceará (UFC), Fortaleza CE, Brazil. E-mail: brazaquino@ufc.br

Maria de Fátima Vieira Severiano

ORCID: https://orcid.org/0000-0002-8793-6658

PhD in Social Sciences Applied to Education from the State University of Campinas (UNICAMP); Full professor at the Federal University of Ceará (UFC), Fortaleza-CE, Brazil. E-mail: fatimaseveriano@gmail.com 